\title{
Evaluation of the Microbial Diversity in Sequencing Batch Reactor Treating Linear Alkylbenzene Sulfonate under Denitrifying and Mesophilic Conditions Using Swine Sludge as Inoculum
}

\author{
Iolanda Cristina Silveira Duarte ${ }^{1 *}$, Lorena Lima de Oliveira ${ }^{2}$, Dagoberto Yukio Okada ${ }^{2}$, \\ Pierre Ferreira do Prado ${ }^{1}$ and Maria Bernadete Amâncio Varesche ${ }^{2}$ \\ ${ }^{I}$ Departamento de Biologia; Universidade Federal de São Carlos; Sorocaba - SP - Brasil. ${ }^{2}$ Departamento de \\ Hidráulica e Saneamento; Escola de Engenharia de São Carlos; Universidade de São Paulo; São Carlos - SP - \\ Brasil
}

\begin{abstract}
The objective of this study was to evaluate the degradation of Linear Alkylbenzene Sulfonate (LAS) in anaerobic sequencing batch reactor (ASBR) under denitrifying conditions using swine sludge as inoculum. The reactor was operated for 104 days with synthetic substrate containing nitrate, and LAS was added later $(22 \mathrm{mg} / \mathrm{L})$. Considering the added mass of the LAS, the adsorbed mass in the sludge and discarded along with the effluent, degradation of the surfactant at the end of operation was $87 \%$, removal of chemical oxygen demand was $86 \%$ and nitrate was $98 \%$. The bacterial community was evaluated by cutting the bands and sequencing of polymerase chain reaction (PCR) fragments and denaturing gradient gel electrophoresis (DGGE). The sequences obtained were related to the phylum Proteobacteria and the alpha-and beta-proteobacteria classes, these bacteria were probably involved in the degradation of LAS. The efficiently degraded LAS in the reactor was operated in batch sequences in denitrifying conditions.
\end{abstract}

Key words: linear alkylbenzene sulfonate (LAS), bioreactor, PCR/DGGE, denitrified

\section{INTRODUCTION}

High concentrations of inhibitory surfactants are often present in industrial wastewater from textile and food manufacturing facilities; their presence can cause negative environmental impacts (Mensah and Forster 2003). Linear alkylbenzene sulfonate (LAS) is used in many different industrial processes, and the household use of these products has resulted in considerable LAS concentrations in sewage systems (Fauster et al. 2003). The most commonly used surfactant in Western Europe is LAS, and the consumption of this surfactant reached 490,000 tons in 2005 (Berna et al. 2007). The average concentration of LAS in the sludge from 51 wastewater treatment plants (Spain) was $8.06 \mathrm{~g} / \mathrm{Kg}$ in 2006-2007 (Cantarero et al. 2012).

Many studies have been conducted to assess the influence of LAS on biodegradation processes (Karahan 2010). Approximately 20 to $50 \%$ of the LAS present in the sewage treatment plants is associated with the suspended solids and is not degradable through aerobic treatment (Angelidaki et al. 2000).The presence of high concentrations of surfactants in the wastewater decreases the

*Author for correspondence: iolanda.duarte@gmail.com 
affinity of biomass to the substrate in aerobic treatment systems, and this effect is more intense in the presence of LAS due to the aromatic ring in this molecule.

LAS can also be found in other environments with low oxygen levels, such as anaerobic sediment, sludge sewage, freshwater and sea water. Wastewater with low concentrations of surfactants can inhibit the anaerobic digestion (Lee et al. 2013). Although LAS degradation under anaerobic conditions has been questioned, some studies have reported considerable efficiency of LAS degradation in anaerobic conditions ( Sanz et al. 2003; Lobner et al. 2005; Delforno et al. 2012, Okada et al. 2013), with LAS influent concentrations ranging between 5 and $14 \mathrm{mg} / \mathrm{L}$.

The anaerobic sequencing batch reactor (ASBR) with suspended sludge was used for the degradation of $22 \mathrm{mg} / \mathrm{L}$ LAS with $53 \%$ efficiency in the absence of co-substrates (Duarte et al. 2010). This reactor was also used for the treatment of various wastewaters such as sanitary landfill leachate for the removal of organic matter and nitrogen (Wang et al. 2013); removal of organic material and sulphate (Mockaitis et al. 2010); applied to personal care industrial wastewater treatment (Oliveira et al. 2010) and producing hydrogen from palm oil mill effluent (Badiei et al. 2012).

In this study, LAS degradation was evaluated in an ASBR containing granular biomass under denitrifying conditions, characterising the microorganisms involved in LAS degradation (Bacteria Domain) by PCR/DGGE.

\section{MATERIAL AND METHODS}

\section{Inoculum}

The inoculum used in the experiment was collected from an Up-flow Anaerobic Sludge Blanket (UASB) reactor that treated the wastewater from a swine-growing facility. This inoculum contained $52 \mathrm{~g} / \mathrm{L}$ of total solids (TS) and $43 \mathrm{~g} / \mathrm{L}$ of total volatile solids (TVS).

\section{Reactor}

Assays were performed in a mechanically stirred anaerobic sequencing batch reactor (ASBR) constructed of borosilicate glass $(20 \mathrm{~cm}$ diameter, $16 \mathrm{~cm}$ height with a working volume of 5-1. A three-blade impeller helix (14 cm width) was used for mechanical stirring (Fig. 1). The batches were incubated for $24 \mathrm{~h}$ (Oliveira et al. 2010, Wang et al. 2013) with agitation at $50 \mathrm{rpm}$ (Duarte et al. 2010) in mesophilic conditions (temperature: $30 \pm$ $\left.1^{\circ} \mathrm{C}\right)$. The batch cycles consisted of a feeding stage with 3-1 of synthetic substrate for $15 \mathrm{~min}$, a reaction phase for $23 \mathrm{~h}$, sedimentation for $30 \mathrm{~min}$ and the effluent discharge for $15 \mathrm{~min}$ (total batch cycle: $24 \mathrm{~h}$ ).

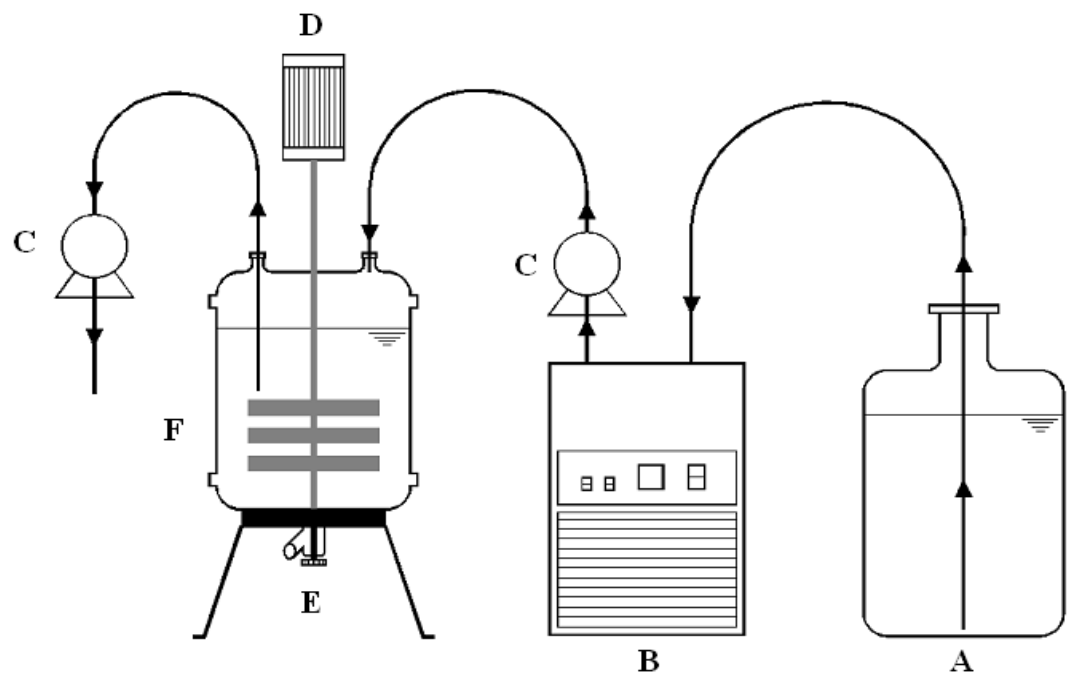

Figure 1 - Schematic representation of an anaerobic sequencing batch reactor. The letters A, B, C, D, $\mathrm{E}$ and $\mathrm{F}$ : correspond to the influent reservoir, thermal batch, peristaltic pumps, impeller, sludge output and reactor. 
The ASBR was operated in two stages: (I) biomass adaptation, and (II) detergent (LAS) addition. Liquid kitchen-cleaning detergent with LAS concentration of $22 \mathrm{mg} / \mathrm{L}$ was added at stage II. The synthetic substrate was produced according to Duarte et al. (2008), which contained $(\mathrm{g} / \mathrm{L})$ yeast extract (0.5), sucrose (0.008), sodium bicarbonate $(0.40)$ and $5.0 \mathrm{~mL} / \mathrm{L}$ of salts solution containing (g/l) $\mathrm{NaCl} 50, \mathrm{MgCl}_{2} \cdot 6 \mathrm{H}_{2} \mathrm{O} 1.4$, and $\mathrm{CaCl}_{2} \cdot 2 \mathrm{H}_{2} \mathrm{O}$ 0.9 . Sodium nitrate was added in a COD: $\mathrm{N}$ ratio of $3: 1$, and the substrate was kept refrigerated at $4{ }^{\circ} \mathrm{C}$ until used to feed the reactor.

\section{Monitoring the performance of de reactor}

Analyses of $\mathrm{pH}$, total solids, chemical oxygen demand (COD), total volatile acid content and nitrate were performed according to the Standard Methods for the Examination of Water and Wastewater (APHA- AWWA-WPCF, 2005). Bicarbonate alkalinity (BA), in the form of $\mathrm{CaCO}_{3}$, was measured as described by Dilallo and Albertson (1969), with modifications proposed by Ripley et al. (1986).

The quantification of LAS was achieved by HPLC using a fluorescence detector, C8 column with an eluting gradient of methanol and sodium perchlorate $(0.075 \mathrm{~mol} / \mathrm{L})$, flux of $0.5 \mathrm{~mL} / \mathrm{min}$ and temperature of $35^{\circ} \mathrm{C}$. At the end of the experiment, the amount of LAS adsorbed into the biomass was measured to be used for calculating the total LAS mass balance in order to quantify the degradation. To measure the LAS adsorbed and precipitated from the biomass, dried samples were extracted with methanol in an ultrasound bath for $30 \mathrm{~min}$, for three times and analysed by HLPC (Duarte et al. 2006).

\section{Molecular Analyses}

The total DNA extraction was performed using the phenol-chloroform-based protocol described by Griffiths et al. (2000). For DGGE analysis, 16S rRNA gene fragments were amplified by the PCR using specific primers for the Bacteria domain (Nielsen et al. 1999) with a GC-clamp (Muyzer et al. 1993). The PCR programs previously described by Nielsen et al. (1999) were used.

DGGE was performed using the Dcode Universal Mutation Detection System (Bio-Rad Laboratories, Hercules, CA, USA), in accordance with the manufacturer's instructions. PCR products were electrophoresed in TAE buffer (1X) at $75 \mathrm{~V}$ for $16 \mathrm{~h}$ at $65^{\circ} \mathrm{C}$ in a polyacrylamide gel
(7.5\%) containing a linear gradient, denaturant ranging from $30 \%$ to $60 \%$.

Most of the bands were excised from the DGGE polyacrylamide, immersed in $20 \mathrm{~mL}$ of ultrapure water for $24 \mathrm{~h}$ and then PCR-amplified with the forward primer EUB968f (without a GC clamp) and the reverse primer 968r. After PCR amplification, the PCR products were purified with Ultraclean_ PCR Clean-up kit (Mobio, USA). The PCR reaction was carried out in an Eppendorf-Mastercycler thermocycler (Eppendorf AG-22331 Hamburg). Both strands of the purified PCR products were sequenced with the primer 968f. Sequencing was performed using an automated ABI 310 PRISM sequencer (Dye terminator Cycle Sequencing Kit - Applied Biosystems, USA) in accordance with the manufacturer's instructions. The GenBank database was searched using the BLAST program. To construct a 16S rRNA gene library, amplification was performed using the bacterial primer pair 27f and 1100r (Lane 1991). A 16S rRNA gene library was constructed from the sludge sample collected at the final operation stage of the reactor. The purified PCR product was ligated into the pGEM-T Easy Vector (Promega, Madison, WI, USA), according to the manufacturer's instructions, and transformed into Escherichia coli JM109 cells. The 16S rRNA gene inserts were then amplified from the plasmid DNA of selected clones using universal M13f and M13r primers (Invitrogen, USA).

Phylogenetic assignment of the microorganisms that were found in the reactor samples was achieved by comparing the 500-bp contiguous $16 \mathrm{~S}$ rRNA gene sequences obtained with the $16 \mathrm{~S}$ rRNA sequence data from reference and type strains and environmental clones deposited in the GenBank (http://www.ncbi.nlm.nih.gov) and RDP (Ribosomal Database Project, WI, USA, http://www.cme.msu.edu/RDP/html/index.html) public databases. Sequence matching was carried out using the BLASTn and RDP programs.

The 16S rRNA partial sequences determined in this study for the bands and clones were deposited in the GenBank under the accession numbers KC793869 to KC793886.

\section{RESULTS AND DISCUSSION}

The reactor was operated for 37 days without LAS, after which the system was stable. The COD 
removal efficiency averaged $90 \pm 6 \%$ for an influent of $426 \pm 20 \mathrm{mg} \mathrm{COD} / \mathrm{L}$ (Table 1); the influent and effluent $\mathrm{pH}$ values were almost identical, at approximately $7.7 \pm 0.4$; the total volatile acids were lower than $70 \mathrm{mg} / \mathrm{L}$; and nitrate removal was highly efficient (99\%), at an initial concentration of $170 \pm 16 \mathrm{mg} / \mathrm{L}$ mass of nitrogen in the form of nitrate. The ASBR operation effluents generated bicarbonate alkalinity $(1697 \pm$
$440 \mathrm{mgCaCO} / \mathrm{L}$ ), which was expected under the denitrifying conditions (Grady et al. 1999). After 37 days of ASBR operation, LAS was introduced at a concentration of $22 \mathrm{mg} / \mathrm{L}$. The addition of detergent did not significantly alter the $\mathrm{pH}$ or COD, and nitrate removal was approximately $98 \%$ and COD removal was $86 \%$, for influent containing $456 \pm 20 \mathrm{mgCOD} / \mathrm{L}$ and $170 \pm 17$ $\mathrm{mgN}-\mathrm{NO}_{3} / \mathrm{L}$ (Table 1).

Table 1 - Mean values of parameters analyzed in the ASBR reactor.

\begin{tabular}{|c|c|c|c|}
\hline Parameter & Influent Mean \pm SD & Effluent Mean \pm SD & Removal (\%) \\
\hline \multicolumn{4}{|l|}{ Stage I (days 1-37) } \\
\hline $\mathrm{pH}$ & $7.6 \pm 0.3$ & $7.7 \pm 0.4$ & - \\
\hline $\mathrm{COD}(\mathrm{mg} / \mathrm{L})$ & $426 \pm 20$ & $42 \pm 25$ & 90 \\
\hline Bicarbonate alkalinity $\left(\mathrm{mg} \mathrm{CaCO}_{3} / \mathrm{L}\right)$ & $1375 \pm 518$ & $1697 \pm 440$ & - \\
\hline $\mathrm{N}-\mathrm{NO}_{3}(\mathrm{mg} / \mathrm{L})$ & $170 \pm 16$ & $1.1 \pm 0.7$ & 99 \\
\hline \multicolumn{4}{|l|}{ Stage II (days 38-104) } \\
\hline $\mathrm{pH}$ & $7.7 \pm 0.2$ & $7.8 \pm 0.3$ & - \\
\hline $\mathrm{COD}(\mathrm{mg} / \mathrm{L})$ & $523 \pm 114$ & $72 \pm 31$ & 86 \\
\hline Bicarbonate alkalinity $(\mathrm{mg} \mathrm{CaCO} / \mathrm{L})$ & $2151 \pm 393$ & $2764 \pm 473$ & - \\
\hline $\mathrm{N}-\mathrm{NO}_{3}(\mathrm{mg} / \mathrm{L})$ & $170 \pm 17$ & $3.12 \pm 1.3$ & 98 \\
\hline Added LAS in influent $(\mathrm{g})$ & 6.4 & - & - \\
\hline Recovered LAS in effluent (g) & - & 0.128 & - \\
\hline LAS adsorbed in sludge (g) & - & 0.16 & \\
\hline LAS degradation $(\%)$ & & & 87 \\
\hline
\end{tabular}

After 44 days, the solids concentration in the ASBR decreased to $73 \%$ and remained almost constant until the end of stage II. Contrary to the previously reported observations (Karahan 2010), it was observed that the LAS non-competitively inhibited the hydrolysis process, with an inhibition coefficient of $500 \mathrm{mgCOD} / \mathrm{L}$, and affected heterotrophic growth through a competitive inhibition mechanism, with an inhibition coefficient of $150 \mathrm{mgCOD} / \mathrm{L}$.

During the 64 days when the ASBR was fed with detergent, $6.4 \mathrm{~g}$ of LAS was applied. A total of $0.16 \mathrm{~g}$ of the biomass was adsorbed, representing $2.5 \%$ of the total LAS applied, and $0.68 \mathrm{~g}$ was recovered in the effluent. After 66 days, the LAS degradation efficiency remained at a level ranging between 70 and $87 \%$, until the end of the experiment (Fig. 2).

Duarte et al. (2010) performed this experiment under the same conditions used in this work, but without the addition of nitrate and achieved 24.5 to $37 \%$ LAS degradation. The co-substrates (sucrose, starch and yeast extract) were removed at an efficiency of 53\%. Using the sludge obtained from a full-scale UASB reactor treating the effluent from a poultry slaughterhouse as inoculum, Delforno et al. (2012) operated an anaerobic expanded granular sludge bed for the removal of LAS; $3.9 \mathrm{~g}$ of LAS mass was applied, $0.32 \mathrm{~g}$ was adsorbed in the solid, $1.69 \mathrm{~g}$ accumulated in the effluent, and $48 \%$ LAS degradation was achieved.

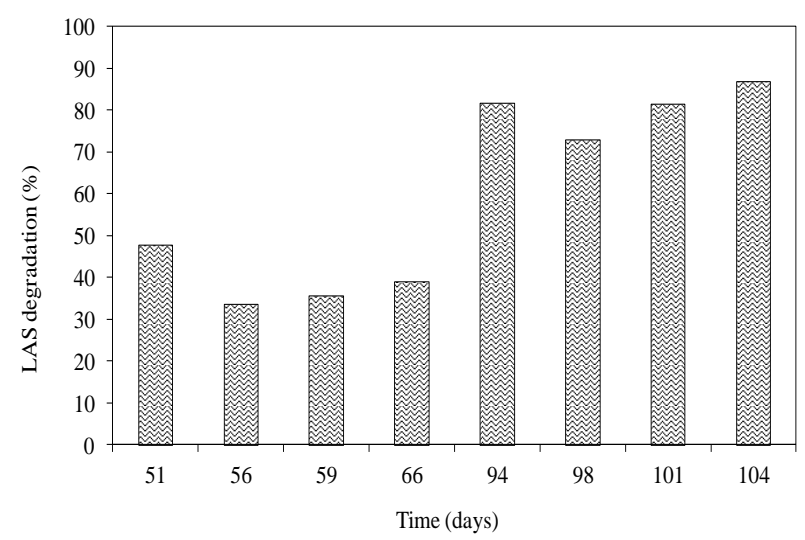

Figure 2 - LAS degradation efficiency in percentage. 
In a UASB reactor using the same sludge, Okada et al. (2013) obtained a 76\% LAS degradation efficiency with a reduction in co-substrates; however, the LAS mass applied was $0.5 \mathrm{~g}$.

Compared to other biodegradation studies, the ASBR used herein under denitrifying conditions exhibited high efficiency. Aerobic studies have suggested an efficiency above 90\% (Gavala and Ahring 2002), and one UASB reactor showed degradation efficiencies ranging from 25 to $85 \%$ (Sanz et al. 2003; Lobner et al. 2005). The higher degradation efficiency in the UASB reactor was obtained under mesophilic conditions $\left(30^{\circ} \mathrm{C}\right)$, a hydraulic retention time of $24 \mathrm{~h}$, and feeding with an isotonic solution (without co-substrates) containing $5 \mathrm{mg} / \mathrm{L}$ of LAS. Unlike those studies, the ASBR used herein under denitrifying conditions was fed with co-substrates (sucrose and yeast extract) and degraded $87 \%$ of the detergent. The high LAS degradation by the ASBR indicated the potential mineralisation of this type of organic molecule by nitrate reduction.

The DGGE profile suggested that the microbial community structure was influenced by the addition of detergent (Fig. 3). The bands marked with arrows were removed, re-amplified, purified and sequenced.

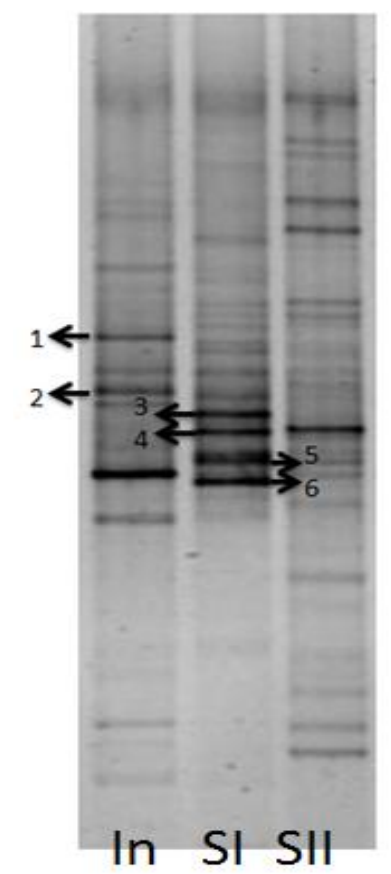

Figure 3 - DGGE profile for Bacteria Domain: (In) inoculums; (SI) Stage I reactor operation without LAS; (SII) Stage II operating with $22 \mathrm{mg} / \mathrm{L}$ of LAS. Numbered bands were excised, reamplified and sequenced.
All of the sequenced bands were related to the phylum Proteobacteria and the classes Alpha and Beta-proteobacteria. Bands 1 and 3 were related to the order Burkholderiales. The species represented by the band 3 in stage I remained in the ASBR after the addition of detergent, although the species represented by the band 1 was not favoured after the addition of detergent. Shingomonas was associated with bands 2 and 4. Shingomonas has been previously used to treat phenanthrene, a polyaromatic hydrocarbon with three benzene rings. These genera might be involved in LAS degradation through the cleavage of the aromatic ring.

Bands 5 and 6 were related to bacteria of the genus Comamonas; one member of this genus, $C$. korensis, can grow under anaerobic conditions and use nitrate as an electron acceptor.

From the sequencing of the $16 \mathrm{~S}$ rRNA, a clone library was constructed in accordance with the final sampling (31 clones); the total fragments averaged $500 \mathrm{bp}$. The phyla Proteobacteria and Gemmatiomonadetes were observed to be dominant in the biomass (Fig. 4).

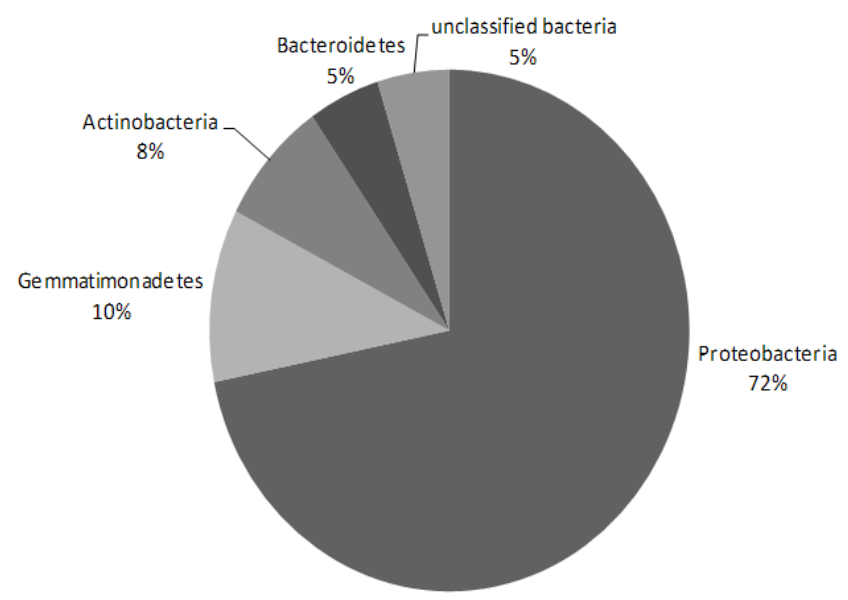

Figure 4 - Phylogenetic representation of the microrganisms sampled during ASBR operation.

The three classes belonging to the Proteobacteria phylum were identified as Beta-Proteobacteria, Alpha- Proteobacteria and Gamma-Proteobacteria. Of the members of the Beta-Proteobacteria class, five clones were assigned to Nitrosomonas (93\%) and six clones were related to the order Burkholderiales and were affiliated with 
Comamonas (99\%). One clone of this class was related to the Acidithiobacillus, which were denitrifying and facultative bacteria that oxidised sulphur compounds. Thesebacteria might have used the sulphur of the LAS molecules instead of nitrate during the reactor operation.

Nitrosomonas bacteria are autotrophic and ammonia-oxidising, and have the ability to denitrify. Only twospecies of Nitrosomonas have been described to produce $\mathrm{N}_{2}$ (Zart and Bock 1998).

In the Alpha-proteobacteria class, clones affiliated with Shingomonas, Mesorhizobium (97\%) and Aquamicrobium (97\%) were identified. Clones related to the Gamma-proteobacteria were not related to any other taxonomic group. Aquamicrobium was first isolated from the activated sludge containing thiophene-2carboxylate as a carbon source and nitrate as an electron acceptor. In the presence of these bacteria, nitrate is reduced to nitrite and to other carbon sources, such as sugars (Bambauer et al. 1998).

Some clones were related to Gemmatimonas (98\%), which belonged to the phylum Gemmatimonadetes. Gemmatimonas is an aerobic bacterium that accumulates polyphosphate granules. This species has been isolated from an aerobic-anaerobic sequencing batch reactor; it uses organic acids and has not been previously described as a denitrifying organism (Zhang et al. 2003). Clones of uncultured bacteria were also found in different nitrogen usage conditions, such as a denitrifying reactor used to treat leachate, an anammox reactor and a batch reactor for ammonia removal via nitrite.

\section{CONCLUSIONS}

The ASBR reactor can be used for the treatment of detergent wastewater in denitrifying conditions. The degradation of LAS was more efficient under denitrifying conditions, with $87 \%$ degradation, compared with the same operation under other anaerobic conditions. The presence of LAS did not impede the removal of organic matter and nitrate. Phylogenetic analysis revealed that the degradation of LAS occurred due to the presence of a mixed microbial community living syntrophically. It could be possible that the degradation of LAS observed in such conditions was performed by Proteobacteria using sulphur and carbon in the aromatic ring.

\section{REFERENCES}

Angelidaki I, Haagensen F, Ahring BK. Anaerobic transformation of LAS in continuous stirred tank reactors treating sewage sludge. The Cler Reviews. 2000; 6: 32-38.

American Public Health Association (APHA, AWWA, WPCF) Standard Methods for the Examination of water and wastewater. Washington, DC: American Public Health Association. 2005.

Badiei M, Jahim JM, Anuar N, Abdullah SRS, Su LS, Kamaruzzaman MA. Microbial community analysis of mixed anaerobic microflora in suspended sludge of ASBR producing hydrogen from palm oil mill effluent. Int J Hydrogen Energ. 2012; 37: 31693176.

Bambauer A, Rainey FA, Stackebrandt E, Winter J. Characterization of Aquamicrobium defluvii gen. nov. sp. nov., a thiophene-2-carboxylate-metabolizing bacterium from activated sludge. Arch Microbiol. 1998; 169: 293-302.

Berna JL, Cassani G, Hager GD, Rehman N, López I, Schowanek D, et al. Anaerobic biodegradation of surfactants - scientific review. Tens Surfact Deterg. 2007; 44: 312-347.

Cantarero S, Prieto CA, López I. Occurrence of hightonnage anionic surfactants in Spanish sewage sludge. J Environ Manage. 2012; 95: 5149-5153.

Delforno TD, Okada DY, Polizel J, Sakamoto IK, Varesche MBA. Microbial characterization and removal of anionic surfactant in an expanded granular sludge bed reactor. Bioresource Technol. 2012; 107: 103-109.

Dillalo R, Albertson OE. Volatile acids by direct tritation. Journal WPCF. 1969; 33: 356-365.

Duarte ICS, Oliveira LL, Buzzini AP, Adorno MAT, Varesche MBA. Development of a method by HPLC to determine LAS and its application in anaerobic reactors. J Brazil Chem Soc. 2006; 17: 1360-1367.

Duarte ICS, Oliveira LL, Mayor MS, Okada DY, Varesche MBA. Degradation of detergent (linear alkylbenzene sulfonate) in an anaerobic stirred sequencing-batch reactor containing granular biomass. Int Biodeter Biodegr. 2010; 64: 129-134.

Duarte ICS, Oliveira LL, Saavedra NK, FantinattiGarboggini F, Oliveira VM, Varesche MBA. Evaluation of the microbial diversity in a horizontalflow anaerobic immobilized biomass reactor treating linear alkylbenzene sulfonate. Biodegradation. 2008; 19: 375-385. 
Fauster P, Vikelsoe J, Sorensen PB, Carlsen L. Phthalates, nonylphenols and LAS in an alternately operated wastewater treatment plant-fate modeling based on measured concentrations in wastewater and sludge. Water Res. 2003; 37: 1288-1295.

Gavala HN, Ahring BK. Inhibition of the anaerobic digestion process by linear alkylbenzene sulfonates Biodegradation. 2002; 13: 201-209.

Grady CPL, Daigger GT, Lim HC. Biological Wastewater Treatment. New York, Marcel Dekker, 1999. 1076.

Griffiths RI, Whiteley AS, O'Donnell AG, Bailey MJ. Rapid method for co-extraction of DNA and RNA from natural environments for analysis of ribosomal DNA- and rRNA-based microbial community composition. Appl Environ Microbiol. 2000; 66: 5488-5491.

Karahan O. Inhibition effect of linear alkylbenzene sulphonates on the biodegradation mechanisms of activated sludge. Bioresource Technol. 2010; 101: 92-97.

Lane DJ. 16S/23S rRNA sequencing. In: Stackebrandt, E., Goodfelow, M. editors. Nucleic acid techniques in bacterial systematic. Chichestre, UK: Wiley. 1991; 115-175.

Lee KH, Park KY, Khanal SK, Lee J. Effects of household detergent on anaerobic fermentation of kitchen wastewater from food waste disposer. $J$ Hazard Mater. 2013; 39-45.

Lobner T, Torang, L, Batstone DJ, Schmidt JE, Angelidaki I. Effects of process stability on anaerobic biodegradation of LAS in UASB reactors. Biotechnol Bioeng. 2005; 89: 759-765.

Mensah KA, Forster CF. An examination of the effects of detergents on anaerobic digestion. Bioresource Technol. 2003; 90: 133-138.

Mockaitis G, Friedl GF, Rodrigues JAD, Ratusznei SM, Zaiat M, Foresti E. Influence of feed time and sulphate load on the organic and sulfate removal in an ASBR. Bioresource Technol. 2010; 101: 6642-6650.

Muyzer G, Dewaal EC, Uitterlinden AG. Profiling of complex microbial-populations by denaturing gradient gel-electrophoresis analysis of polymerase chain reaction-amplified genes-coding for $16 \mathrm{~S}$ ribosomal-RNA. Appl Environ Microbiol. 1993; 59: 695-700.
Nielsen AT, Liu WT, Filipe C, Grady L, Molin S, Stahl DA. Identification of a novel group of bacteria in sludge from a deteriorated biological phosphorus removal reactor. Appl Environ Microbiol. 1999; 65: 1251-1258.

Oliveira RP, Ratusznei SM, Rodrigues JAD, Zaiat M, Foresti E. Interaction effects of organic load and cycle time in an ASBR applied to a personal care industrial wastewater treatment. J Environ Manage. 2010; 91: 2499-2504.

Okada DY, Delforno TP, Esteves AS, Sakamoto IK, Duarte ICS, Varesche MBA. Optimization of linear alkylbenzene sulfonate (LAS) degradation in UASB reactor by varying bioavailability of LAS, hydraulic retention time and specific organic load rate. Bioresource Technol. 2013; 128: 125-133.

Ripley LE, Boyle WC, Converse LC. Improved alkalinetric monitoring for anaerobic digestion of high-strength wastes. Journal WPCF. 1986; 58: 106111.

Sanz JL, Culubret E, Ferrer J, Moreno A, Berna JL. Anaerobic biodegradation of linear alkylbenzene sulfonate (LAS) in up-flow anaerobic sludge blanket (UASB) reactors. Biodegradation. 2003; 14: 57-64.

Wang K, Wang S, Zhu R, Miao L, Peng Y. Advanced nitrogen removal from landfill leach without addition of external carbon using a novel system coupling ASBR and modified SBR. Bioresource Technol. 2013; 134: 212-218.

Zart D, Bock E. High rate of aerobic nitrification and denitrification by Nitrosomonas eutropha grown in a fermentor with complete biomass retention in the presence of gaseous $\mathrm{NO}_{2}$ or NO. Arch Microbiol. 1998; 169: 282-286.

Zhang H, Sekiguchi Y, Hanada S, Hugenholtz P, Kim H, Kamagata Y, Nakamura K. Gemmatimonas aurantiaca gen. nov., sp a gram-negative, aerobic, polyphosphate-accumulating microrganism, the first cultured representative of the new bacterial phylum Gemmatimonadetes phyl. Nov. Int $J$ Syst Evol Microbiol. 2003; 53: 1155-1163. 